\title{
Petrography and Mineralogy of Jabal Sanam Gypsum Rocks, Southern Iraq
}

\author{
Abdul-Aziz M. Al-Hamdani \\ Depatrmrnt of Geology \\ College of Science \\ Mosul University \\ Abdul-mutalib H. Al-marsoumi \\ Department of Geology \\ College of Science \\ Basrah University
}

\section{Basim H. Soltan}

Department of Geology

College of Science

Basrah University

(Received 10/9/2004 , Accepted 24/11/2004)

\begin{abstract}
Jabal Sanam is a salt plug, with cap rocks characterized by the presence of evaporitic sequence, where gypsum forms large part of this sequence. The field observations showed that gypsum occurs in form of massive beds and veins, In addition four petrological types of gypsum are recognized; alabastrine, selenite, fibrous, and rocky gypsum. The examination of (61) thin sections besides the X-ray analyses proved that the available gypsum represents the dominant mineral with few to trace amount of anhydrite, dolomite and quartz. Petrographically, four types of gypsum textures are also identified; alabastrine, porphyroblastic, fibrous and granular. All these textures suggest a secondary origin of Jabal Sanam gypsum due to the hydration of pre-existing anhydrite. The hydration occurs when the cap rocks approach the ground surface. The connate and groundwater form the main source of hydration water.
\end{abstract}

\section{صخاربة ومعنية صخور جبسوم جلمسنلم، جنوي العرق}

\section{الملغص}

جلبسنلم عبارة عن لمطوانة ملحية تمتاز صخور غائها بوجود تتايع المتبخرات فيها و ويث مل

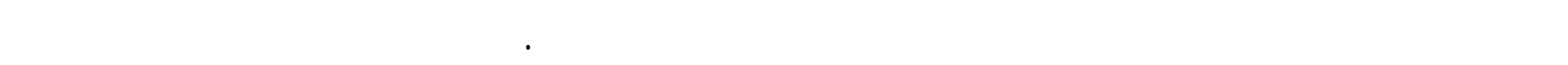

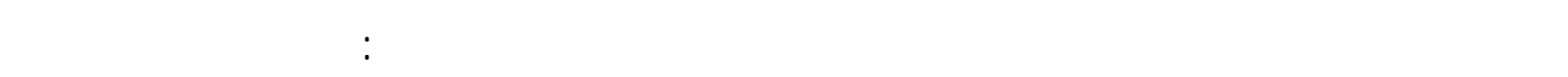

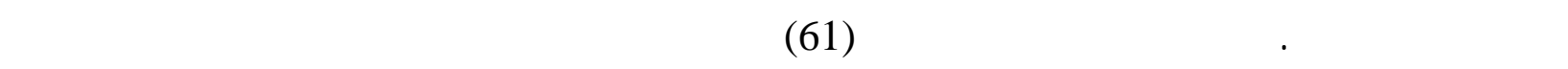

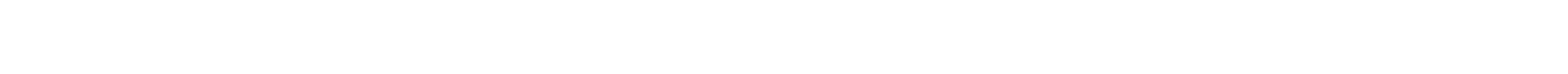

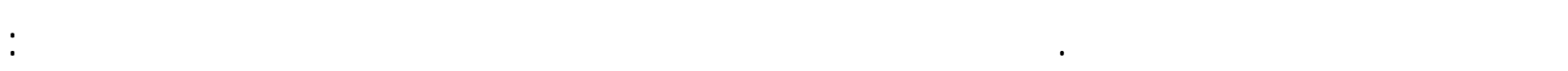

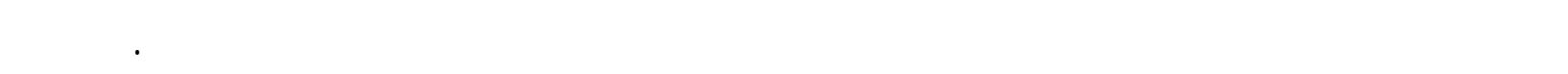

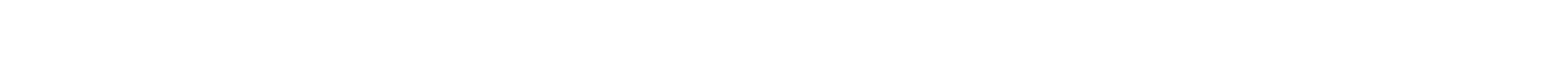




\section{الملحية المنفعة نحو الأعلى، وذلك لدى اقترابها منسطح الأرض، وان الميه القديمة المحبوسة والمي له الجوفية هي المصدر الأسلسي لميل التميؤ.}

\section{INTRODUCTION}

Jabal Sanam (Hump Mountain) forms prominent geomorphic and geologic features in southern Iraq. The nomenclature of Sanam was acquired from similarity between this structure and the hump of Camel. Really, it is not a mountain (in Arabic word Jabal) as the public use to call it, because its height is about (152 m.), which is less than that of the mountain height (600 m.) above sea level, as defined by (Fairbridge, 1968). In the present study the term Jabal is used for the purpose of nomenclature.

Jabal Sanam is being located about $(45-\mathrm{km})$ southwest Basrah City, near the IraqiKuwait borders (Fig. 1). Based on the physiographic subdivision of Iraq presented by (Buday and Jassim, 1987), Jabal Sanam occurs within the Dibdibba plain, whereas tectonically, it is located within quasiplatform foreland (Numan, 2001).

Many authors, like (William, 1949; Leitch, 1953; Masin et al., 1965; and Al-Naqib, 1970) agree that Jabal Sanam is a salt plug resulting from the salt injection within the overlying sedimentary cover. Al-Muttory (2002) came to conclude that the motivating force has resulting from the difference in density between anhydrite and the overlying sediments.

The age of Jabal Sanam rocks is determined to be Pre-Cambrian (580 M.Y) depending on the radioactive isotope study (Buday and Jassim, 1987). Later, Soltan (2002) suggested logically the Infra Cambrian age for the evaporitic sequence, while the (Late Devonian-Early Carboniferous) age for other sediments in Jabal Sanam structure is determined based on pollens and spores found in coal seams within the studied sequence.

The present study attempts at using the mineralogical and petrographical characteristics of the gypsum beds within cap rocks of Jabal Sanam plug to delineate the mechanism of gypsum-anhydrite diagenetic processes.

\section{GEOLOGIC SETTING}

Geomorphologically, Jabal Sanam is the most important feature prominent within the study area. It is surrounded by low relief Dibdibba plain. Geologically, this structure is still ambiguous .It is believed to be salt plug; (i.e.) dome that has acquired the present form during Late Tertiary period (Al-Naqib, 1970). The shape of Jabal Sanam is elliptical with long axis $(1.7 \mathrm{~km})$ running (NW-SE), and consisting of central dome with many parasitic small domes situated in the south and eastern parts of the structure. The drainage systems are shallow and radial in nature; many sand dunes were found on the western rims of the structure. Field observation revealed that these dunes might be formed when the sedimentbearing winds (domestically Al-Shamaly) encounter an obstacle (Jabal Sanam) that slows them down. 


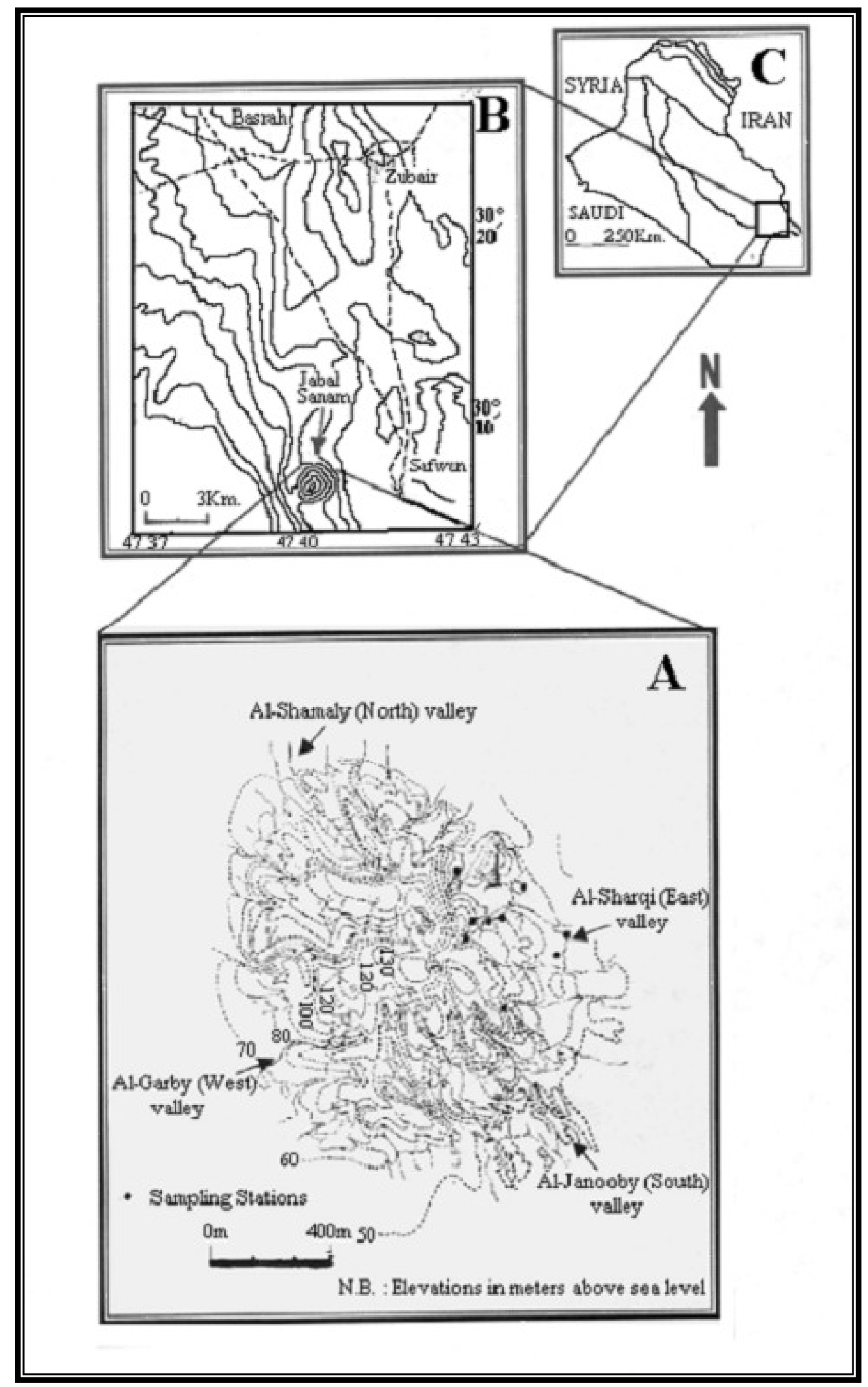

Fig.1: Location and topographic map of Jabal Sanam, Southern Iraq (After Al-Naqib, 1970 (A); Al-Dabbas, 1993 (B) and Numan, 2001 (C)). 
Generally, the sedimentary strata at the top of the just dome are commonly broken by normal faults (Billings, 1974). Therefore, the present sedimentary sequence exhibits great complexity and heterogeneity (Plate, A6). According to Al-Naqib (1970) the exposed Jabal Sanam sedimentary sequence could be divided lithologically into four units; green marl, gypsum, bercciated limestone, and clastics of Dibdibba Formation (Miocene-Pliocene) (Fig. 2). Additionally, heterogeneous assemblages of igneous and metamorphic rocks were also recorded. The origin of the metamorphic and igneous rocks

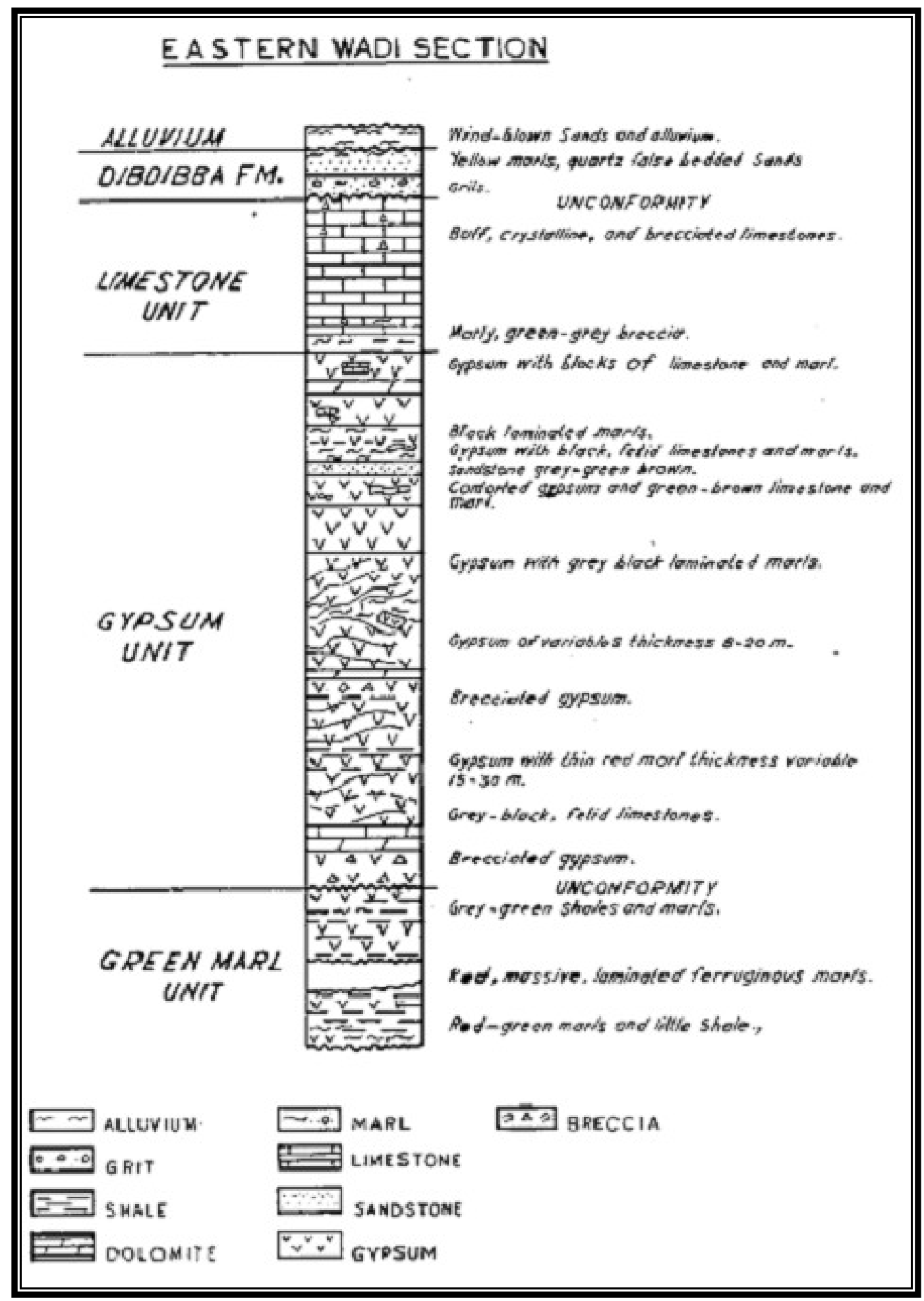

Fig.2: Lithological section of Jabal Sanam structure (After Al-Naqib, 1970). 
that found in Jabal Sanam structure may be belong to the basement complex. It is believed that the emerged parts of the basement rocks were crushed during the creeping of Hurmuz salts (Cambrian). Than, they uplifted in a form of variable blocks within the intruded salt pulses upwards which formed the Sanam diapair (Soltan, 2002).

\section{METHODOLOGY}

Sixty one rock samples were systematically collected from the exposed Jabal Sanam gypsum beds. The collection was conducted along selected traverses and stations, from which (61) thin sections were prepared, and examined to delineate their mineralogical and textural characteristics.

\section{MINERALOGY}

The X-ray diffractogram of representative sample (Fig.3) shows that there are three dominant minerals: Gypsum, Anhydrite and Dolomite. The petrographic examination of the available thin sections revealed the presence of the different proportion of the minerals stated above.

\section{PETROLOGY}

The field observation, hand specimen description and petrography characteristics revealed the following gypsum varieties:

1. Alabastrine gypsum: This type of gypsum comprises the white and smoky rocks in Jabal Sanam, which commonly form irregular masses, and consist of fine crystals (Plate-A1a).

2. Selenite gypsum: It is characterized by broad foliated form, which is cleaved into several colourless and transparent cleavages sheets (Plate-A1b). They occur either as veins or clusters growing within the vugs of massive gypsum. The size of the individual crystal ranges from microscopic up to $(10 \mathrm{~cm}$.) in width and about $(40 \mathrm{~cm}$.) in length; twinning according to (swallow-tail) law is common (Plate-A2).

3. Fibrous gypsum: It is also called satin-spar, it has silky luster and greasy feeling, usually take the shape of the fractures, vugs, and bedding planes (Plate-A1c.). The individual crystal ranges in size between microscopic up to (30 cm.). According to (Holliday, 1978), it is thought that the satin-spar veins are presumably derived during the transformation of anhydrite into gypsum. Pettijohn (1975) pointed out that this transformation involves an increase in volume of (30-50\%). Hence, the excess calcium sulphate is taken into solution, and then precipitated as satin-spar. On the other hand, (Sherman et al., 1972 in Rouchy et al., 1993) considered that in a semi-closed system, the expulsion of waters from underlying sediments via fractures is responsible for the formation of satin- spar.

4. Rock gypsum: It is characterized by fine crystals and impurities, usually contains various amounts of terrigenous and organic materials, which give them various colours. 


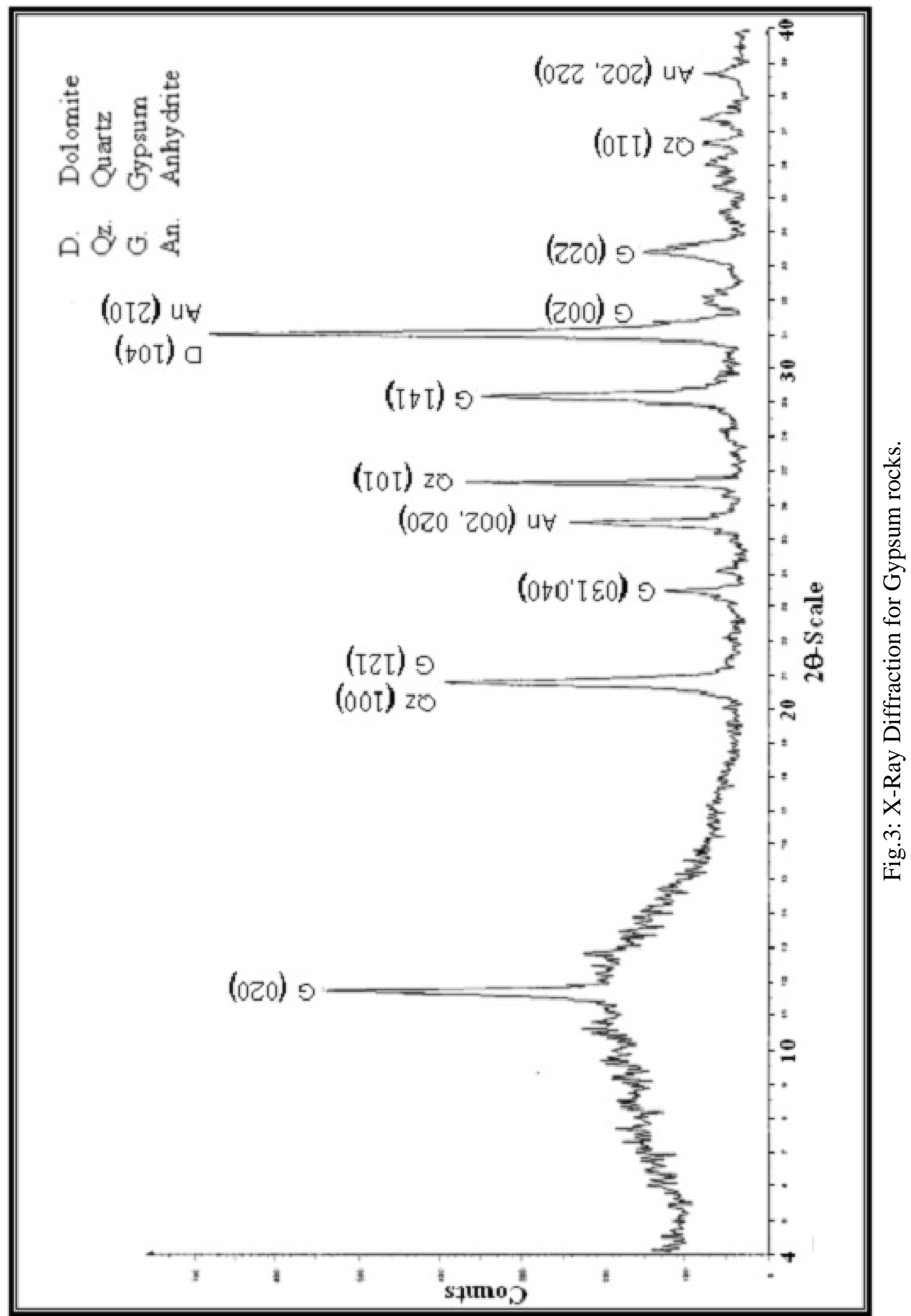




\section{Plate.A}
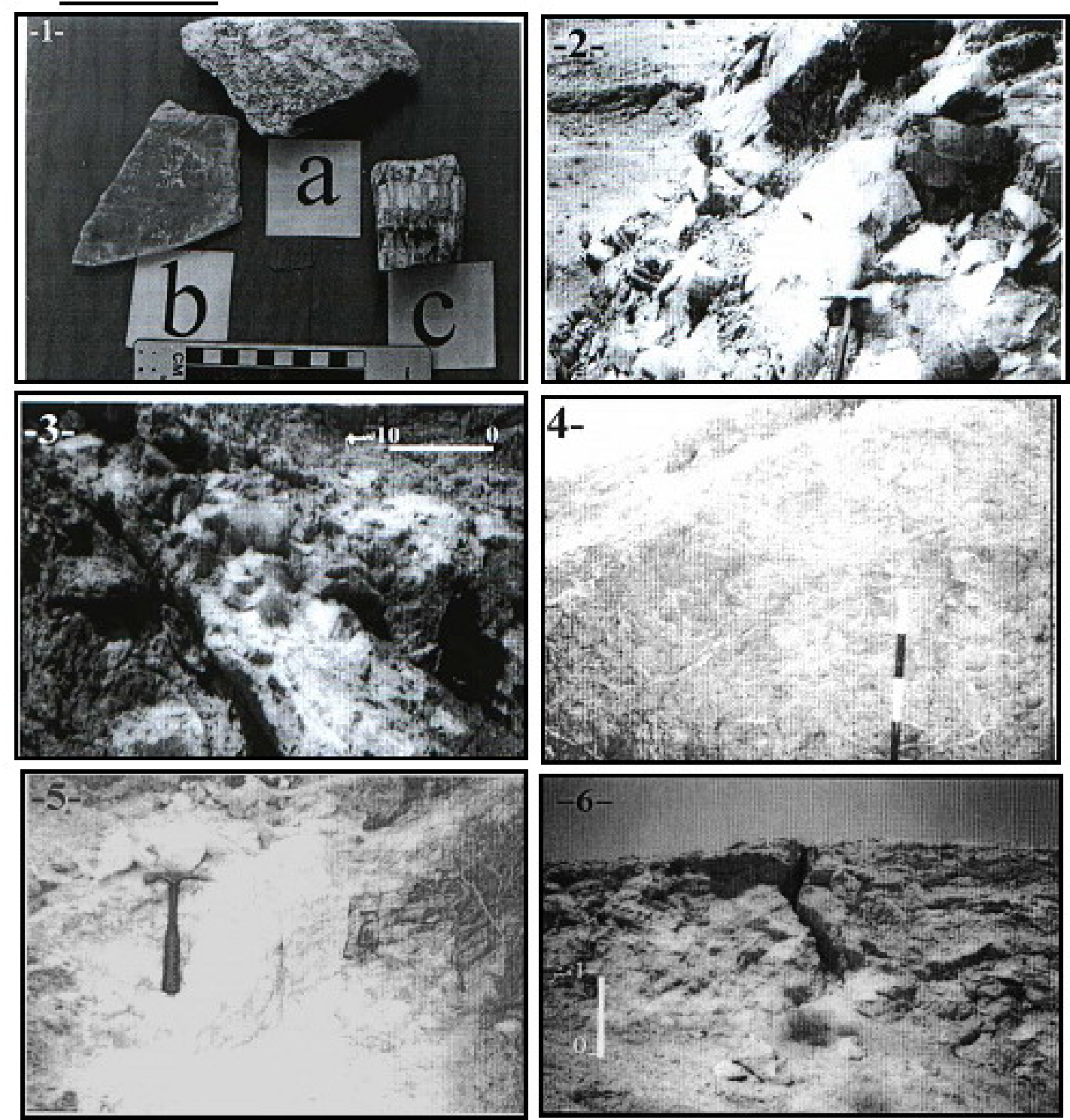

P.A1 a: Alabastrine gypsum

P.1b: Selenite gypsum

P.A1 c: Fibrous gypsum

P.A2: B1oks of Selenite shows Swallow-till structure.

P.A3: One of the large-scale gypsum veins in Jabal Sanam.

P.A4: Complex systems of gypsum veins in rock outcrops.

P.A.5: Nodular gypsum structure.

P.A.6: Complex \& Faulted outcrops of gypum rocks in Jabal Sanam. 


\section{STRUCTURES OF GYPSUM ROCKS}

The field observations revealed the following structures within Jabal Sanam gypsum rocks:

1. Gypsum veins: It is very common structure in Jabal Sanam rocks. The sedimentary rocks on top of the salt plug are commonly fractured. Generally, secondary gypsum fills the weakness planes forming a network of selenite and satin-spar veins (Plates-A 3 and 4), presumably, the anhydrite-gypsum transformation contributes to the calcium sulphate necessary for secondary gypsum precipitation.

2. Nodular Gypsum: Gypsum nodules are less common. They have spherical and elongated shapes ranging in size from two to ten centimeters in diameter. They are compacted and interlocking firmly (Plate-A5). The available gypsum nodules are cemented by gypsum, marl, and carbonate materials forming clusters. It is worth mentioning here, that the present gypsum nodules are somewhat similar in both; mode of occurrence and composition, to those of Fa'tha Formation (Middle Miocene) in Mosul area reported by (Mustafa, 1980).

\section{PETROGRAPHY}

The petrographic study has been carried out in details on all gypsum thin sections, the following types of gypsum textures were recognized:

1. Alabastrine gypsum texture: very fine crystals, which are difficult to identify, characterize this texture. Therefore, it is also called microcrystalline gypsum or micritic texture (Plate-B1). This type of textures is very common in the area under study. The formation of such texture results from the rehydration of an anhydritic precursor that formed under various conditions (Rouchy et al., 1993).

2. Porphyroblastic gypsum texture: It is characterized by the presence of large gypsum crystals known as porphyroblast, such crystals are embedded in a finely crystalline groundmass of gypsum and anhydrite (Plate-B2). This texture is characterized by presence of inherited relicts of anhydrite. This suggests that the gypsum in the studied area be of secondary origin derived by the rehydration of pre-existing anhydrite. Gypsum porphyroblast represent early formed secondary gypsum near the equilibrium conditions of gypsum and anhydrite (Fig. 4), with distal growing centres permitting the porphyroblast to grow into large size (Holliday, 1970).

3. Fibrous gypsum texture: Two types of this texture have been identified; coarse and fine fibrous textures. These textures are usually found in fractures of different rocks, some times clusters of crystals may be developed as a result of crystal lamella union forming the felty texture (Plate-B3).

4. Granular gypsum texture: In this texture, the porphyroblasts are large and interlocking firmly. When the porphyroblasts exhibit a preferred orientation because of the overburden load, then the texture is called integrated granular texture (Plate-B4). On the other hand, the un-integrated texture is characterized by its random distribution of porphyroblasts (Plate-B5). 
Plate. B
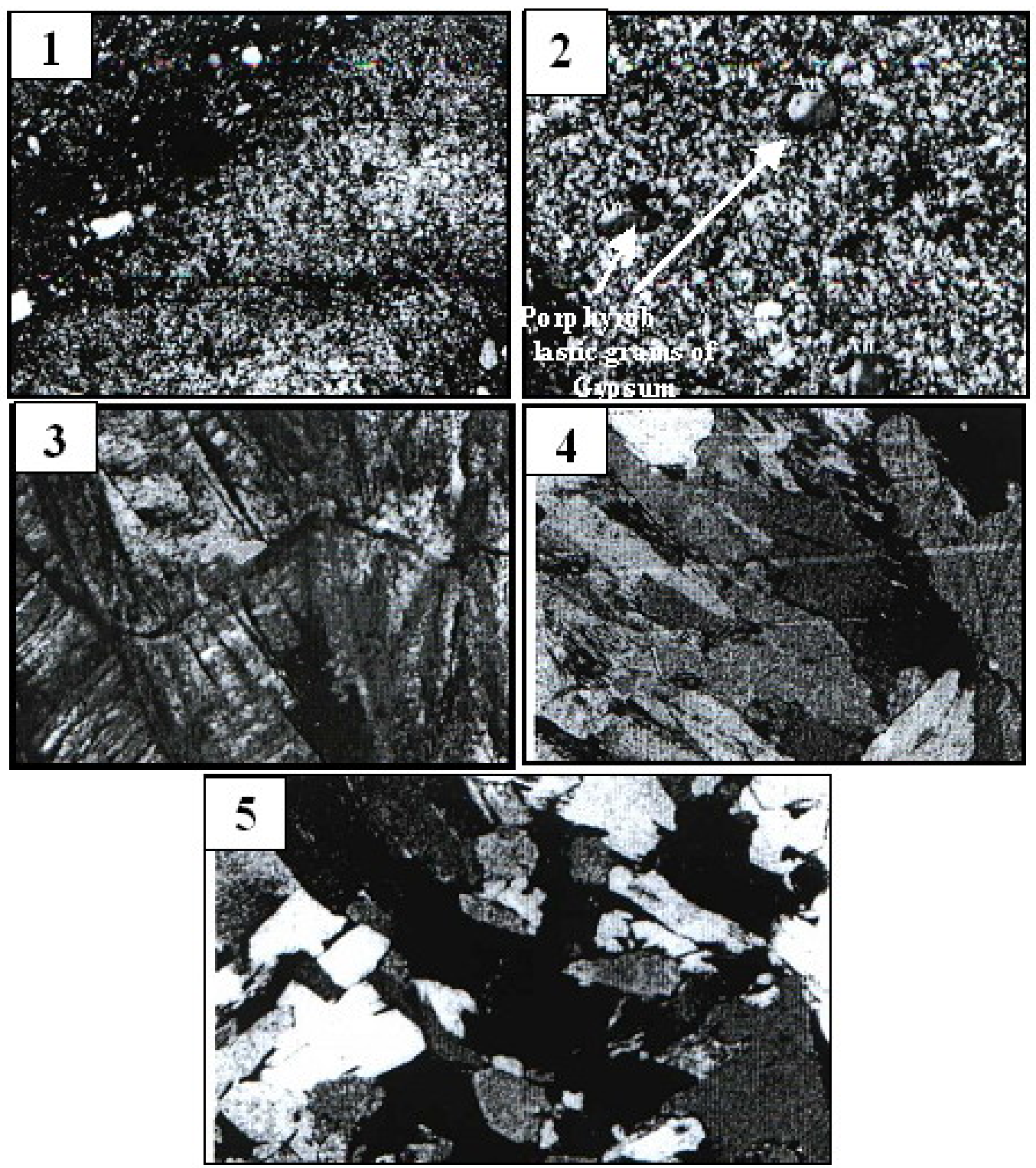

P.B1: Micritic texture in alabastrine gypsum (XPL.100x).

P.B2: Porphyroblastic texture in gypsum rocks (XPL.100x).

P.B3: Felty texture in fibrous gypsum (XPL.100x).

P.B4: Integrated granular textures (XPL.100x).

P.B5: Un-integrated granular texture (XPL.100x). 


\section{DIAGENESIS}

The following diagenitic processes are identified within studied gypsum:

1. Gypsification process is commonly documented in Jabal Sanam rocks. This process is considered as a sort of retrogressive metamorphism, since, gypsum and anhydrite can replace each other depending upon the environmental conditions (Holliday, 1970). Generally, this process occurs under the supergene environmental conditions (low temperature and pressure, and active fluid movements) .The diagenitic cycle of gypsum and anhydrite is shown in Figure (4). The obtained petrographical and mineralogical data illustrate the secondary origin of the available gypsum, and the solution-precipitation is the most expected mechanism for the hydration of pre- existing anhydrite.

Authors, like (Bundy, 1956, Holliday, 1970; Blatt et al., 1980 and Rouchy, et al., 1993) agreed that the calcium sulphate is firstly deposited as gypsum, and then transformed into anhydrite. The temperature required for transformation lies between $\left(40-58{ }^{\circ} \mathrm{C}\right)$, but can be lowered to $\left(20-25^{\circ} \mathrm{C}\right)$ in the presence of sodium chloride. The scenario of Jabal Sanam rocks gypsification can be summarized as follows: the calcium sulphate were initially precipitated as gypsum owing to the availability of lagoonal brine waters rich in sodium chloride developed under arid conditions. Then it changed to anhydrite after burial to great depth (Blatt et al., 1980). Finally, the anhydrite again is changed to gypsum as the salt plug approachs the ground surface (Fig. 4). The sources of waters necessary for hydration are connate and ground water (phereatic water) (Soltan, 2002).

2. Recrystallization occurs in gypsum due to the effect of stress caused by overburden load. In the present gypsum rocks, the process of recrystallization took place over three main stages; the first recrystallization (under low stress) characterized by irregular interlocking crystals (Plate-B5). With increased stress, the second stage of recrystallization develops, and during which gypsum crystals become larger with undulose extinction and appear as crystal patches (Plate-B4). The final or advanced stage of recrystallization is characterized by the large euhedral crystals called porphyroblasts, which are devoid of premonition inherited anhydrite relicts due to the exsolved of such relicts during crystal growth.

\section{CONCLUSIONS}

From the results of mineralogy and petrography of Jabal Sanam gypsum rocks, the following conclusions were drawn:

The gypsum of Jabal Sanam is of secondary origin derived by the hydration of pre-existing anhydrite.

The solution- precipitation is the most probable mechanism for anhydrite transformation into gypsum.

Gypsification and recrystallization are the main diagenetic processes that proceed on Jabal Sanam gypsum rocks.

According to (Holliday, 1970) opinion, the excess of calcium sulphate resulted from transformation of gypsum in to anhydrite was exhausted in forming fibrous (satin-spare) and selenite gypsum. 


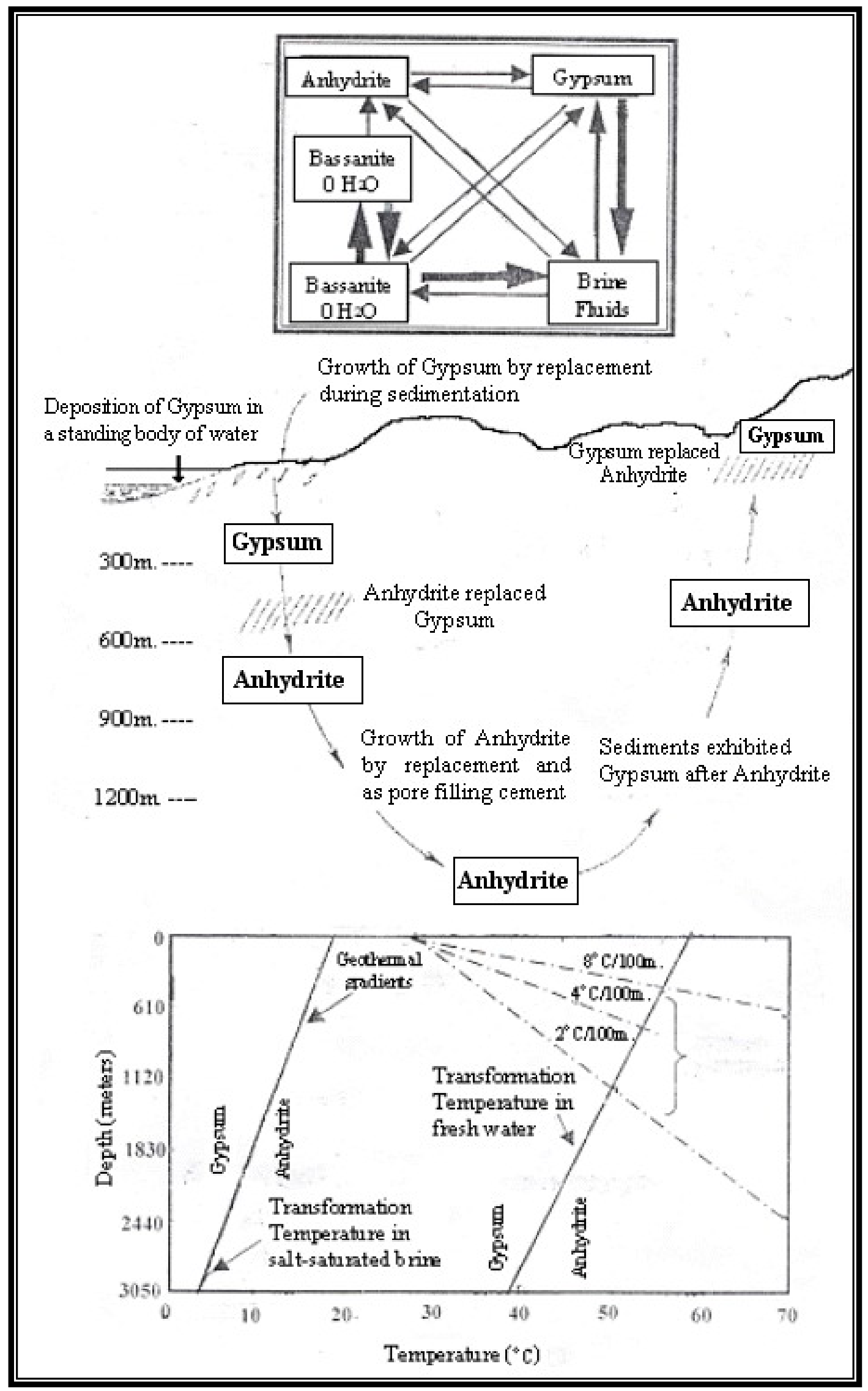

Fig.4: Gypsum-Anhydrite diagenitic cycle with T-P plot for Gypsum and Anhydrite transformation in fresh and brine fluids (After Holser, 1979 in Change et al., 1998 and Blatt et al., 1980). 


\section{REFERENCES}

Al-Dabbas, M.A., 1993. Sediments-Water Interchanges of Boron during dry and wet conditions in Upper Ddibdibba Formotion, South of Iraq. Iraqi Geol Jour., 26(2), pp.1-19.

Al-Muttory, W.K., 2002. Structure and tectonism of Jabal Sanam, Southern Iraq. Unpubl. M. Sc. Thesis, Basrah Univ., 93p. (in Arabic).

Al-Naqib, K.M., 1970. Geology of Jabal Sanam, south of Iraq. Jour. Geol. Soc. Iraq, Vol.3, No.1, pp.9-36.

Billings, M.P., 1974. Structural Geology, $3^{\text {rd }}$ ed., Prentice Hall, Inc., New Delhi, 606p.

Blatt, H., Middleton, G.and Murray, R., 1980. Origin of Sedimentary Rocks. PrenticeHall, Inc., USA, 782p.

Buday, T. and Jassim, S.Z., 1987. The Regional geology of Iraq, Vol. 2, Tectonism, Magmatism, and metamorphism. S.E. Geol. Surv. Min. Invest., Baghdad, Iraq, 333p.

Bundy, W.M., 1956. Petrology of Gypsum-Anhydrite Deposits in south western Indiana, Jour. Sed. Pet., Vol. 26, pp.240-252.

Chang, L.L.Y., Howie, R.A. and Zuissman, M.A.,1998. Rock Forming Minerals. The Geological Society of London, U.K., 383p.

Fairbridge, R.W., 1968. The Encyclopedia of Geomorphology. Reinhold Book Corporation, New York, 1278p.

Holliday, D.W., 1970. The Petrology of Secondary Gypsum Rocks, A review. Jour. Sed. Pet., Vol.40, No.2, pp.734-747.

Holliday, D.W., 1978. Petrology of Basal Purbeck (Upper Jurassic) Gypsum Rocks of the Broadoak Boreholes, Sussex. Institute of Geological Sciences, Broadoak Boreholes Sussex, Her Majesty Stationary Office, London, pp.31-38.

Leitch, H.C.B., 1953. Summary Report of Finding from visit to Jebel Sanam. Unpub. Rep. No. 43, S.E. Geol. Surv. Min. Invest., Baghdad, Iraq.

Masin, J., Underwood, J.R. and Safa Al-Din, T., 1965. Jabal Sanam, Southern Iraq, Progress Report on Origin and Age. Bull. Of Science, Baghdad, Vol.8, pp.47-61.

Mustafa, A.Z.M., 1980. Sedimentological Studies of The Lower Fars Formation in Sinjar Basin- Iraq. Unpubl. M. Sc. Thesis, Univ. of Mosul, Iraq, 122p.

Numan, N.M.S., 2001. Discussion on Dextral Transpression in Late Cretaceous continental Collision, Sanadaj-Sirjan Zone, Western Iran. Jour. Struc. Geol., Vol.23, pp.2033-2034.

Pettijohn, F.J., 1975. Sedimentary Rocks. Harper and Row Publishers, Inc., New York, 628 .

Rouchy, J.M., Bernet-Rollands, M.C., Maurin, 1993. Descriptive Petrography of Evaporites; Application in the field, Subsurface and the Laboratory, Evaporite sequences in Petroleum Exploration, 1. Geological Methods, Editions Techniq, Internet, pp.71-123.

Soltan, B.H., 2002. Petrology and Origin of Jabal Sanam Structure Southern Iraq. Unpubl. M. Sc. Thesis, Basrah Univ., 86p. (in Arabic).

William, W.R., 1949. Report on Jebel Sanam, Unpubl. Report No. 42, S. E. Geol. Surv. Min. Invest., Baghdad, Iraq. 